\title{
CD52 wt Allele
}

National Cancer Institute

\section{Source}

National Cancer Institute. CD52 wt Allele. NCI Thesaurus. Code C51036.

Human CD52 wild-type allele is located within $1 \mathrm{p} 36$ and is approximately $3 \mathrm{~kb}$ in length.

This allele, which encodes CAMPATH-1 antigen immunoprotein, plays a role in inflammatory response and carbohydrate trafficking; however, neither role has been substantiated. 